\title{
PENGARUH IDENTITAS SOSIAL DAN CO-CREATION TERHADAP NIAT BERPERILAKU ANGGOTA KOMUNITAS ONLINE VW: EFEK MODERASI NOSTALGIA
}

\author{
Badri Munir Sukoco (badri@feb.unair.ac.id) \\ Untung Teko TP \\ Fakultas Ekonomi dan Bisnis, Universitas Airlangga
}

\begin{abstract}
Developing relationships with customers through brand community is the recent tool for marketers for customer relationship management (CRM) program. The existence of a community, especially virtual, depends on the members' participation as well as their recommendation to others. Previous studies indicate that members' participation and recommendation depends on how deep is their identification toward the community. This article argues that social identification itself is not enough, unless the members engage in cocreation activities by exchanging knowledge with other members (co-consumption) and producers (co-production). Further, this article further argues that the effect of social identity on members' co-creation and behavioral intentions will be moderated by their nostalgia proneness. We conducted survey among Volkswagen Indonesia CyberCommunity (VICC) members as one of the legendary brand in Indonesia. The results indicate that direct effect of social identity on members' behavioral intentions is greater than indirect effect through co-creation. The moderating effect of nostalgia proneness is significant on the relationship between social identity and behavioral intentions, in which the effect is larger when members' identification is low. Managerial and academic implications are further discussed in this paper.
\end{abstract}

Keywords: social identity, co-creation, behavioral intentions, nostalgia proneness, and virtual brand community

\section{PENDAHULUAN}

Virtual brand community merupakan kelompok loyalis sebuah merek dengan struktur yang dibangun namun tidak terbatas secara geografis (Muniz dan O'Guinn, 2001), yang berbagi, bertukar, dan menciptakan pengetahuan terkait merek tersebut melalui internet (Rheingold, 1994; Sproull dan Arriaga, 2007). Baik yang dibentuk oleh konsumen maupun yang difasilitasi oleh produsen, virtual brand community ada untuk melayani konsumen loyalis, seperti pengguna Linux (Bagozzi dan Dholakia, 2006a), Apple Newton (Muniz dan Schau, 2005), Nike (Füller, Jawecki, dan Mühlbacher, 2007), dan banyak lainnya.

Brand community memungkinkan anggota komunitas untuk bertukar informasi dan pengetahuan terkait produk, yang terkadang membantu perusahaan untuk menyelesaikan masalah ketika konsumen menghadapi masalah (Bagozzi dan Dholakia, 2006b; Muniz dan Schau, 2005), dan juga membantu mereka untuk berbagi ide dengan konsumen lainnya co-consumption (Brown, Kozinets, dan Sherry, 2003; Füller dkk., 2007; Wu dan Sukoco, 2010). Kelompok penelitian lainnya mengindikasikan bahwa anggota brand community juga aktif dalam meberikan masukan atau saran terkait dengan produk yang dihasilkan produsen co-production (Brown dkk., 2003; Füller dkk., 2007; Füller, Matzler, dan Hoppe, 2008; Prahalad dan Ramaswamy, 2004).

Penelitian-penelitian sebelumnya menyatakan bahwa aktifitas berbagi pengetahuan tersebut dilakukan sebagai upaya anggota komunitas untuk mengidentifikasikan dirinya dengan komunitas (Bagozzi dan Dholakia, 2006a, 2006b). Identifikasi dengan komunitas menjadikan mereka memiliki koneksi secara intrinsik dengan anggota komunitas yang lain (Muniz dan O'Guinn, 2001) dan pada saat yang sama meningkatkan perilaku oposisi terhadap merek lain (Thompson dan Sinha, 2008). Selain itu, identifikasi yang kuat terhadap 


\section{Badri Munir Sukoco Untung Teko TP}

brand community juga akan mendorong anggota untuk berpartisipasi secara aktif dan merekomendasikannya kepada kolega guna menjaga keberlangsungan komunitas tersebut (Algesheimer, Dholakia, dan Hermann, 2005; Sukoco, Wu, dan Loh, 2011).

Brand community yang aktif dan besar juga tertopang oleh legendarisnya merek yang menjadi acuan, misalnya Harley Davidson (McAlexander dan Schouten, 1998; Schouten and McAlexander, 1995), MG Rover (Leigh, Peters, dan Shelton, 2006), VW (Brown dkk., 2003). Namun penelitian sebelumnya jarang yang mendiskusikan apakah perilaku berbagi pengetahuan tersebut memiliki level yang berbeda tergantung pada keterikatan atau pengalaman mereka pada merek yang dimaksud. Menggunakan konsep preferensi nostalgia (nostalgia proneness - Holbrook, 1993; Holbrook dan Schindler, 1996), peneliti mengasumsikan bahwa pengaruh identitas anggota pada brand community terhadap perilaku mereka tergantung pada pengalaman atau konstruksi sosial terhadap merek tersebut. Semakin legendaris merek yang dijadikan simbol sebuah brand community, maka pengaruh identitas sosial akan semakin menguat. Menggunakan VW sebagai merek yang menjadi patron, peneliti menguji asumsi tersebut.

\section{LANDASAN TEORI DAN PENGEMBANGAN HIPOTESIS}

\section{Identitas Sosial}

Menurut Tajfel (1978), seseorang mendapatkan identitas sosialnya melalui kesadaran diri bahwa dirinya merupakan anggota sebuah kelompok, memiliki ikatan emosional, dan memiliki evaluasi yang positif terhadap kelompok tersebut. Berdasarkan hal tersebut, Ellemers, Kortekaas, and Ouwerkerk (1999, hal. 372) berpendapat bahwa identitas sosial seseorang terdiri atas 3 komponen: kognitif (kesadaran kognitif bahwa dia menjadi anggota kelompok tersebut - kategorisasi diri), afektif (perasaan keterlibatan secara emosional dengan kelompok tersebut - komitmen afektif), dan evaluatif (konotasi nilai positif dan negatif yang melekat pada keanggotaan kelompok tersebut - harga diri kelompok). Ketiga dimensi tersebut telah diuji construct dan nomological validity-nya oleh Bergami dan Bagozzi (2000) dan Bagozzi dan Lee (2002). Identitas sosial membentuk dan mendesak perilakuperilaku tertentu yang memberikan kemanfaatan atas keanggotaan sebuah kelompok (Ellemers dkk., 1999; Bergami dan Bagozzi, 2000). Dalam studi terkait brand community, Algesheimer dkk. (2005) menemukan bahwa identifikasi dengan klub mobil menjadikan anggota memiliki keterlibatan dan keterikatan yang tinggi diantara anggota.

\section{Co-Creation}

Komunitas virtual dipenuhi dengan banyak kegiatan yang berkaitan dengan berbagi pengetahuan dan informasi. Berbagi pengetahuan merupakan perilaku dari anggota komunitas virtual yang membagikan pengetahuan dan informasi yang dimilikinya kepada anggota lainnya (Ryu, Ho, dan Han, 2003). Berdasarkan pendapat Vargo dan Lusch (2004), aktifitas berbagi pengetahuan tersebut merupakan sarana bagi produsen untuk melakukan proses penciptaan bersama dengan konsumennya (co-creation) yang dapat digolongkan menjadi dua, yakni co-consumption dan co-production (Wu dan Sukoco, 2010). Coconsumption terjadi ketika anggota komunitas mendistribusikan pengetahuan atau informasi yang dimilikinya kepada anggota lainnya di komunitas virtual (Ryu dkk., 2003), sedangkan co-production terjadi ketika anggota komunitas mendistribusikan pengetahuan atau informasi yang dimilikinya kepada produsen guna meningkatkan kegunaan atau kualitas produk yang dikonsumsi (Brown dkk., 2003; Fuller dkk., 2007).

\section{Preferensi Nostalgia}

Holbrook dan Schindler (2003) mendefinisikan nostalgia proneness sebagai preferensi seseorang terhadap berbagai obyek (orang, tempat, atau barang) yang sedang populer ketika masa muda seseorang (baik masa kecil, remaja, dewasa, atau bahkan sebelum dilahirkan) dan akan menjadi preferensi seseorang sepanjang sisa hidupnya. Terkait dengan 
masa sebelum dilahirkan, preferensi nostalgia tidak hanya berasal dari pengalaman pribadi seseorang saja, namun juga muncul melalui proses pembangkitan memori kolektif atas suatu obyek pada suatu era di masa lalu (Lowenthal, 1985), atau dengan mengkombinasikan material-material "kuno" menjadi tradisi-tradisi yang dapat memenuhi kebutuhan masa sekarang (Hobsbawm dan Ranger, 1983). Lebih lanjut, Holbrook dan Schindler (1996) menunjukkan bahwa kecenderungan seseorang terhadap nostalgia tidak terasosiasi dengan demografis usia ataupun gender, dan setiap individu dapat memiliki kecenderungan terhadap nostalgia yang berbeda-beda. Holbrook dan Schindler (2003) juga berpendapat bahwa preferensi nostalgia tidak harus muncul melalui pengalaman pribadi seseorang. Preferensi tersebut dapat dibangkitkan oleh berbagai benda, seperti suvenir, foto, barang-barang antik, dan hadiah dapat menjadi material-material yang dapat membangkitkan memori dan perasaan yang kuat akan masa lalu (Belk, 1991).

\section{Pengembangan Hipotesa}

Sebagai komunitas online pengguna mobil VolksWagen, anggota VICC mengkategorisasikan dirinya secara kognitif terhadap komunitasnya dengan adanya kesamaan ketertarikan terhadap mobil VolksWagen, mengevaluasi dirinya dengan adanya penghargaan terhadap keanggotaannya dalam komunitas, dan anggota juga melibatkan dirinya secara emosional dengan komunitasnya sebagaimana yang telah disampaikan pada bagian sebelumnya. Seorang individu yang merasa bahwa dirinya telah menjadi bagian dari grup (identitas sosialnya terbentuk) maka akan memiliki komitmen untuk bersama-sama mencapai tujuan dari grup tersebut, dimana komitmen untuk mencapai tujuan bersama tersebut akan membentuk perilaku anggota grup (Stets \& Burke, 2000). Algesheimer dkk (2005) menunjukkan bahwa identitas sosial anggota dalam komunitas European Car Clubs mendorong partisipasi aktif anggota dalam kegiatan komunitas, aktif memberikan rekomendasi kepada orang lain, dan memiliki loyalitas yang tinggi terhadap komunitas.

Identifikasi anggota terhadap brand community merupakan salah satu karakteristik dari sebuah brand community (Muniz dan O'Guinn, 2001). von Loewenfeld (2006) dan Algesheimer dkk (2005) berpendapat bahwa identifikasi anggota terhadap brand community merupakan determinan utama dari perilaku anggota komunitas. Sebagaimana dijelaskan pada bagian diatas, Elemers dkk (1999) dan Bergami dan Bagozzi (2000) menunjukkan bahwa identifikasi tersebut memiliki tiga komponen yaitu komponen kognitif, evaluatif, dan afektif. Muniz dan O'Guinn (2001) menunjukkan bahwa anggota komunitas komputer Macintosh saling berbagi pengetahuan untuk saling membantu meningkatkan fungsionalitas komputer Macintosh mereka. Algesheimer akk (2005) berpendapat bahwa identifikasi anggota terhadap brand community memiliki konsekuensi positif terhadap komunitas dengan membantu anggota yang lain sehingga dengan demikian meningkatkan nilai diri anggota tersebut dan nilai anggota lainnya yang pada akhirnya meningkatkan nilai anggota komunitas secara keseluruhan. Brown dkk (2003) menunjukkan bahwa produsen VolksWagen mendapatkan banyak masukan dari komunitas terkait launching VW New Beetle, dan Fuller dkk (2007) menunjukkan bahwa komunitas Niketalk banyak memberikan kontribusi terhadap desain inovatif dan kreatif produk sepatu merek Nike. Sehingga,

$\mathrm{H}_{1}$ : Identitas sosial yang dimiliki oleh anggota VICC memiliki pengaruh yang positif terhadap (a) co-creation dan (b) niat berperilaku mereka terkait dengan komunitas.

Koh dan Kim (2004) menunjukkan bahwa aktifitas berbagi informasi (knowledge sharing) dalam komunitas online di Korea Selatan berkontribusi dalam membangun loyalitas anggota terhadap komunitasnya, mendorong partisipasi anggota dalam kegiatan komunitasnya dan mendorong anggota untuk merekomendasikan komunitasnya kepada orang lain. Wu dan Sukoco (2010) menunjukkan bahwa aktifitas berbagi informasi dalam komunitas online iPhone di Thailand berpengaruh terhadap partisipasi anggota dalam 


\section{Badri Munir Sukoco Untung Teko TP}

kegiatan kolektif, keinginan untuk merekomendasikan, dan perilaku anggota untuk tetap loyal terhadap komunitasnya. Sehingga,

$\mathrm{H}_{2}$ : Aktifitas co-creation yang dilakukan oleh anggota VICC memiliki pengaruh yang positif terhadap niat berperilaku mereka terkait dengan komunitas.

Pembahasan sebelumnya mengindikasikan bahwa identitas sosial memiliki pengaruh langsung terhadap co-creation dan niat berperilaku anggota komunitas. Penelitian ini lebih lanjut berargumentasi bahwa pengaruh identitas sosial terhadap niat berperilaku tidak akan sebesar ketika pengaruh tersebut melalui co-creation. Menurut Sukoco dan Setiawan (2013), identifikasi diri anggota terhadap komunitas - sense of community - memiliki pengaruh yang lebih besar bilamana anggota memiliki frekuensi yang tinggi untuk berbagi pengetahuan co-consumption dan co-production. Meskipun identifikasi diri terhadap komunitas tinggi, namun bila kurang berinteraksi dengan anggota lainnya cenderung memiliki niat untuk berpartisipasi atau merekomendasikan komunitas rendah (Zhang, 2010).

$H_{3}$ : Pengaruh identitas sosial yang dimiliki oleh anggota VICC terhadap niat berperilaku mereka akan dimediasi oleh aktifitas co-creation yang mereka lakukan.

VolksWagen merupakan salah satu merek yang sejak dahulu eksis (old brands) dan dimungkinkan menimbulkan preferensi nostalgia pada konsumen (Holbrook dan Schindler, 2003). Hal ini diperkuat oleh pendapat Brown dkk. (2003) dalam studinya terkait retrobranding dan berargumentasi bahwa VW dapat menimbulkan preferensi nostalgia. Komunitas yang memiliki ketertarikan yang sama terhadap old brands seperti VolksWagen cenderung memiliki preferensi nostalgia yang tinggi sehingga ikatan dan hubungan yang diantara anggota komunitas tersebut semakin kuat (Kozinets, 2002, p. 21). Hal ini sejalan dengan pendapat Brown dan Humphreys (2002) bahwa kecenderungan terhadap nostalgia memberikan kontribusi terhadap pembentukan identitas anggota komunitas sosial dan memperkuat komitmen untuk mencapai tujuan bersama suatu komunitas sosial melalui perilaku anggota komunitasnya (Stets dan Burke, 2000).

Brown dkk (2003) menunjukkan bagaimana produsen VolksWagen berkolaborasi dan mencari informasi dari penggemar Old Beetle dalam komunitas brand untuk menciptakan personalitas yang baru bagi New Beetle dan mendapatkan masukan dari penggemarnya untuk menyempurnakan produknya (co-production). Preferensi nostalgia yang tinggi akan memperkuat nilai moral (normative commitment) anggotanya karena adanya perasaan yang lebih aman dan lebih tidak komersial (Schouten dan McAlexander, 1995). Dapat disimpulkan bahwa pengaruh identitas sosial terhadap co-creation dan niat berperilaku akan semakin menguat bilamana anggota komunitas memiliki preferensi nostalgia yang tinggi dibandingkan rendah. Sehingga,

$\mathrm{H}_{4}$ : Pengaruh identitas sosial terhadap (a) co-creation dan (b) niat berperilaku akan dimoderasi oleh preferensi nostalgia yang dimiliki. Pengaruh tersebut akan menguat bilamana mereka memiliki preferensi nostalgia yang tinggi dibandingkan yang rendah.

\section{METODE PENELITIAN}

Peneliti menggunakan 6 item yang dikembangkan oleh Bergami dan Bagozzi (2000) dan Bagozzi dan Lee (2002) untuk mengukur identitas sosial responden untuk ketiga dimensi (kognitif, afektif, dan evaluatif) masing-masing 2 item seperti yang digunakan oleh Bagozzi dan Dholakia (2006a, 2006b). Niat berperilaku terkait dengan komunitas merk menggunakan 4 item yang dikembangkan oleh Algesheimer dkk. (2005), yang mana niat untuk berpartisipasi dan niat untuk merekomendasikan masing-masing memiliki 2 item. Variabel cocreation (co-production-4 item dan co-consumption-3 item), peneliti menggunakan item yang dikembangkan oleh Wu dan Sukoco (2010) dan digunakan oleh Sukoco dan Aditya (2011). Ketiga variabel tersebut menggunakan 5 skala Likert, yang mana angka 1 menunjukkan ketidaksetujuan dan angka 5 menunjukkan kesetujuan. 
Adapun preferensi nostalgia diukur menggunakan 10 item yang dikembangkan oleh Holbrook (1996) dengan 6 skala Likert, dimana angka 1 menunjukkan ketidaksetujuan dan angka 6 menunjukkan kesetujuan. Penggunaan skala yang berbeda (yaitu 5 dan 6 skala Likert) dilakukan sebagai salah satu cara untuk mengurangi efek self-generated validity (Feldman dan Lynch, 1988) berdasarkan saran dari Podsakoff, MacKenzie, Lee, dan Podsakoff (2003). Penelitian ini juga melakukan balancing order, yakni mengurutkan pertanyaan tidak secara berurutan (misalnya, niat berperilaku diletakkan diawal, diikuti oleh co-creation, preferensi nostalgia, dan kemudian identitas sosial).

Komunitas yang dipilih adalah VW-IndonesiaCyberCommunity (VICC - http://www.VWindonesiacybercommunity.com). VICC dipilih karena aktifitas, interaksi, dan hubungan yang kuat diantara anggotanya serta kualitas pengelolaan komunitas tersebut layaknya komunitas sosial sebagaimana yang dijelaskan oleh Muniz \& O'Guinn (2001). Pengelolaan komunitas online VICC dilakukan oleh Global Moderator dan Administrator yang terlibat secara aktif dalam komunitas. Hal lain yang tidak kalah penting dalam pertimbangan pemilihan komunitas online VICC adalah komunitas tersebut mewadahi penggemar VolksWagen secara utuh, yaitu penggemar Old VolksWagen (air-cooled VW) dan New VolksWagen (water-cooled VW), dan keanggotannya yang tidak dibatasi oleh geografis. VICC didirikan di Jakarta sejak tahun 2008 atas dasar kecintaan terhadap mobil VolksWagen dan terus berkembang hingga saat ini. Saat penelitian ini dilakukan, terdapat 2.200 member dan lebih dari 92.000 posting dalam lebih dari 4.700 topik. Jumlah posting dan anggota yang besar menunjukkan bahwa anggota VICC saling berinteraksi satu sama lain secara reguler dan memiliki hubungan yang kuat diantara anggota.

Setelah mendapatkan izin dari administrator VICC, peneliti mendistribusikan kusioner secara online yang dilaksanakan antara November hingga Februari 2013. Terdapat 107 responden yang berpartisipasi dalam penelitian ini, dimana sebagian besar telah memposting lebih dari 4.000 kali (51 orang, 47,7\%) dan responden yang memposting antara 1.000-4.000 kali sebanyak 31 orang (29\%). Terdapat 36 responden yang berusia diatas 40 tahun $(33,60 \%)$, sedangkan responden dengan usia di bawah tersebut sebanyak 71 orang $(66,40 \%)$. Mayoritas responden telah menempuh pendidikan S1 (67 orang, 62,60\%) dan berpenghasilan lebih dari 5 juta rupiah per bulan (74 orang, 69,20\%). Terdapat 71 orang $(66,40 \%)$ yang telah menjadi anggota dan aktif di VICC lebih dari 4 tahun, sedangkan responden yang kurang dari 4 tahun sebanyak 36 orang $(33,60 \%)$.

\section{HASIL DAN PEMBAHASAN}

Pendekatan partial least square (Smart PLS 2.0; Chin, 1998) digunakan untuk memodelkan jalur yang mengestimasikan pengukuran dan parameter-parameter structural dalam structural equation model (SEM) karena dalam penelitian ini menggunakan variabel reflektif (identitas sosial, berbagi pengetahuan, niat berperilaku, dan preferensi nostalgia) dan formatif (variabel kontrol) secara bersamaan. Untuk mengukur properti psikometri dari instrument penelitian, peneliti menggunakan prosedur yang digunakan oleh Kleijnen, Ruyter, and Wetzels (2007), menggunakan indikator reflektif pada seluruh konstruk (lihat Tabel 1). Model null tanpa hubungan struktural diestimasikan, dan reliabilitas dievaluasi dengan ratarata composite scale reliability (CR) dan average variance extracted (AVE) (Chin, 1998; Fornell and Larcker, 1981). Untuk semua pengukuran, semua nilai CR diatas 0,700 dan AVE juga diatas 0,500 (Fornell and Larcker, 1981). Selain itu, convergent validity dievaluasi dengan melihat pada standardized loadings dari pengukuran yang digunakan (Chin, 1998), dan semuanya menunjukkan angka lebih dari 0,500. Empat item pada preferensi nostalgia yang memiliki loadings dibawah 0,500 dihapus dalam penghitungan lebih lanjut.

Menurut Ghozali (2011), variabel dengan indikator formatif tidak dapat dianalisis dengan hanya melihat convegent validity dan composite reliability seperti halnya konstruk reflektif. Untuk itu, analisa tambahan dengan menilai koefisien regresi dan signifikansinya dilakukan untuk kinerja perusahaan. Hasil analisa juga menunjukkan bahwa koefisien regresinya 


\section{Badri Munir Sukoco Untung Teko TP}

memiliki tingkat signifikansi yang diharapkan, sehingga semua variabel yang digunakan dalam penelitian ini memiliki validitas dan reliabilitas yang diharapkan.

Untuk mengecek dampak dari potensi common method variance (CMV) dalam penelitian ini, 2 langkah pengujian dilakukan. Pertama, menggunakan uji Harman's one-factor test dengan menempatkan semua item pertanyaan dalam principal component factor analysis (Podsakoff dan Organ, 1986). Hasilnya menunjukkan bahwa tidak ada satu faktor yang mendominasi (terdapat 6 faktor yang dihasilkan dengan $75,108 \%$ adalah total variance, dan faktor pertama mempunyai $17,980 \%$ variance). Kedua, uji discriminant validity dilakukan mengikuti prosedur yang dikembangkan oleh Fornell and Larcker (1981). Bilamana nilai AVE untuk setiap variabel lebih besar dari kuadrat korelasi variabel tersebut, maka dapat dikatakan bahwa antar variabel penelitian memiliki discriminant validity. Tabel 2 menunjukkan hasil tersebut dan terlihat bahwa nilai masing-masing AVE lebih besar dari nilai kuadrat masing-masing korelasi variabel penelitian.

Untuk menguji hipotesa, peneliti menggunakan structural equation modeling dengan metode partial least square (PLS) menggunakan Smart PLS 2.0 (Chin, 1998). Mengingat variabel kontrol merupakan variabel formatif, penggunaan PLS tepat dalam menganalisa model penelitian yang menggunakan variabel reflektif dan formatif. Prosedur yang digunakan dengan menghasilkan sub-sampel 300 dari kasus yang dipilih secara random, dengan penggantian, dari data aslinya. Koefisien jalur kemudian dihasilkan untuk subsampel yang terpilih. t-statistik dihitung untuk semua koefisien, berdasarkan stabilitas antar sub-sampel yang mengindikasikan jalur mana yang signifikan secara statistik. Penelitian ini menggunakan second-order factor untuk identitas sosial, berbagi pengetahuan, and niat berperilaku anggota komunitas online VW; hal ini juga ditunjang oleh tingginya Cronbach's Alpha (diatas 0,700) untuk masing-masing dimensi. Sedangkan variabel nostalgia menggunakan first-order factor.

\section{Tabel 1 - Validitas dan Reliabilitas Variabel Penelitian}

\begin{tabular}{|c|c|c|c|c|}
\hline Kode & Item & $\begin{array}{l}\text { Outer } \\
\text { loadings }\end{array}$ & $\begin{array}{l}\text { Composite } \\
\text { reliability }\end{array}$ & $\begin{array}{l}\text { Cronbach's } \\
\alpha\end{array}$ \\
\hline \multicolumn{5}{|c|}{ Identitas Sosial } \\
\hline \multicolumn{5}{|c|}{ Identitas kognitif } \\
\hline $\mathrm{IK} 1$ & $\begin{array}{l}\text { Saya menilai adanya kesesuaian antara identitas } \\
\text { personal saya (personal identity) dengan identitas } \\
\text { komunitas online VICC }\end{array}$ & 0,846 & 0,865 & 0,701 \\
\hline IK2 & $\begin{array}{l}\text { Saya menilai adanya kesesuaian antara citra diri } \\
\text { saya (self-image) dengan identitas komunitas } \\
\text { online VICC }\end{array}$ & 0,899 & & \\
\hline \multicolumn{5}{|c|}{ Identitas Afektif } \\
\hline$|A|$ & $\begin{array}{l}\text { Saya merasa telah menjadi bagian dari komunitas } \\
\text { online VICC }\end{array}$ & 0,936 & 0,913 & 0,811 \\
\hline IA2 & $\begin{array}{l}\text { Saya mempunyai perasaan memiliki (feeling of } \\
\text { belongingness) terhadap komunitas online VICC }\end{array}$ & 0,896 & & \\
\hline \multicolumn{5}{|c|}{ Identitas Evaluatif } \\
\hline IEI & $\begin{array}{l}\text { Saya adalah anggota yang bernilai (valuable) bagi } \\
\text { komunitas online VICC }\end{array}$ & 0,949 & 0,956 & 0,909 \\
\hline IE2 & $\begin{array}{l}\text { Saya adalah anggota yang penting (important) } \\
\text { bagi komunitas online VICC }\end{array}$ & 0,965 & & \\
\hline \multicolumn{5}{|c|}{ Co-creation } \\
\hline \multicolumn{5}{|c|}{ Co-consumption } \\
\hline Cocl & $\begin{array}{l}\text { Ketika berpartisipasi dalam Kaskus online, saya } \\
\text { biasanya aktif berbagi pengetahuan dengan yang } \\
\text { lain }\end{array}$ & 0,814 & 0,855 & 0,747 \\
\hline
\end{tabular}


Coc2 Ketika membahas isu yang kompleks, saya

0,846

biasanya terlibat dalam interaksi tingkat lanjut dengan anggota lain

Coc3 Saya biasanya melibatkan diri dalam diskusi

\section{Co-production} dengan anggota lain tentang topik yang umum daripada yang spesifik

Copl Saya sering memposting kritik saya tentang produk VW

Cop2 Saya biasanya menghabiskan banyak waktu untuk me-review produk VW baru dan mempostingnya di thread

Cop3 Setiap kali saya tahu bagaimana menangani masalah yang dihadapi produk VW tertentu, saya menyarankan perusahaan untuk menyelesaikannya

Cop4 Saya melakukan hal untuk membuat pengembangan dan inovasi perusahaan produk VW menjadi lebih mudah

\begin{tabular}{|c|c|c|c|c|}
\hline \multicolumn{5}{|c|}{ Niat Berperilaku } \\
\hline \multicolumn{5}{|c|}{ Niat untuk berpartisipasi } \\
\hline NuP 1 & $\begin{array}{l}\text { Saya bermaksud untuk tetap mengikuti aktifitas } \\
\text { komunitas VICC bulan depan. }\end{array}$ & 0,882 & 0,878 & 0,723 \\
\hline NuP2 & $\begin{array}{l}\text { Saya bermaksud untuk tetap berpartisipasi secara } \\
\text { aktif dalam aktifitas komunitas VICC. }\end{array}$ & 0,888 & & \\
\hline \multicolumn{5}{|c|}{ Niat untuk merekomendasi } \\
\hline NuR 1 & $\begin{array}{l}\text { Saya akan merekomendasikan komunitas VICC } \\
\text { pada penggemar VW }\end{array}$ & 0,915 & 0,925 & 0,839 \\
\hline NuR2 & $\begin{array}{l}\text { Jika teman atau saudara mencari komunitas mobil } \\
\text { VW, saya tentunya menyarankan komunitas VICC }\end{array}$ & 0,940 & & \\
\hline \multicolumn{5}{|c|}{ Preferensi nostalgia } \\
\hline Nosl & Berbagai hal tidak dibuat seperti dulu dibuat & 0,562 & 0,795 & 0,724 \\
\hline Nos2 & Berbagai hal terasa lebih baik di masa lalu & 0,737 & & \\
\hline Nos3 & $\begin{array}{l}\text { Pada masa lalu, semua masalah terlihat begitu } \\
\text { jauh }\end{array}$ & 0,735 & & \\
\hline Nos4 & $\begin{array}{l}\text { Berbagai produk terasa semakin buruk dan semakin } \\
\text { buruk }\end{array}$ & 0,710 & & \\
\hline Nos5 & $\begin{array}{l}\text { Ketika saya lebih muda, saya lebih bahagia } \\
\text { dibandingkan saat ini }\end{array}$ & 0,605 & & \\
\hline Nos6 & $\begin{array}{l}\text { Bintang film masa kini dapat belajar dari bintang } \\
\text { film masa lalu }\end{array}$ & & & \\
\hline Nos7 & $\begin{array}{l}\text { Pahlawan olahraga yang sebenarnya telah lama } \\
\text { mati dan pergi }\end{array}$ & & & \\
\hline Nos8 & $\begin{array}{l}\text { Terkadang, saya hampir berharap bahwa saya } \\
\text { dapat kembali ke rahim Ibu saya }\end{array}$ & & & \\
\hline Nos9 & Kita mengalami penurunan dalam kualitas hidup & & & \\
\hline Nos 10 & $\begin{array}{l}\text { Dibandingkan musik klasik, musik masa kini } \\
\text { sebagian besar adalah sampah }\end{array}$ & 0,579 & & \\
\hline
\end{tabular}

Catatan: Item pertanyaan yang tercetak miring dihapus untuk analisa lebih lanjut dikarenakan outer loadings yang rendah. 
Badri Munir Sukoco

Untung Teko TP

Tabel 2 - Deskriptif dan Matriks Korelasi

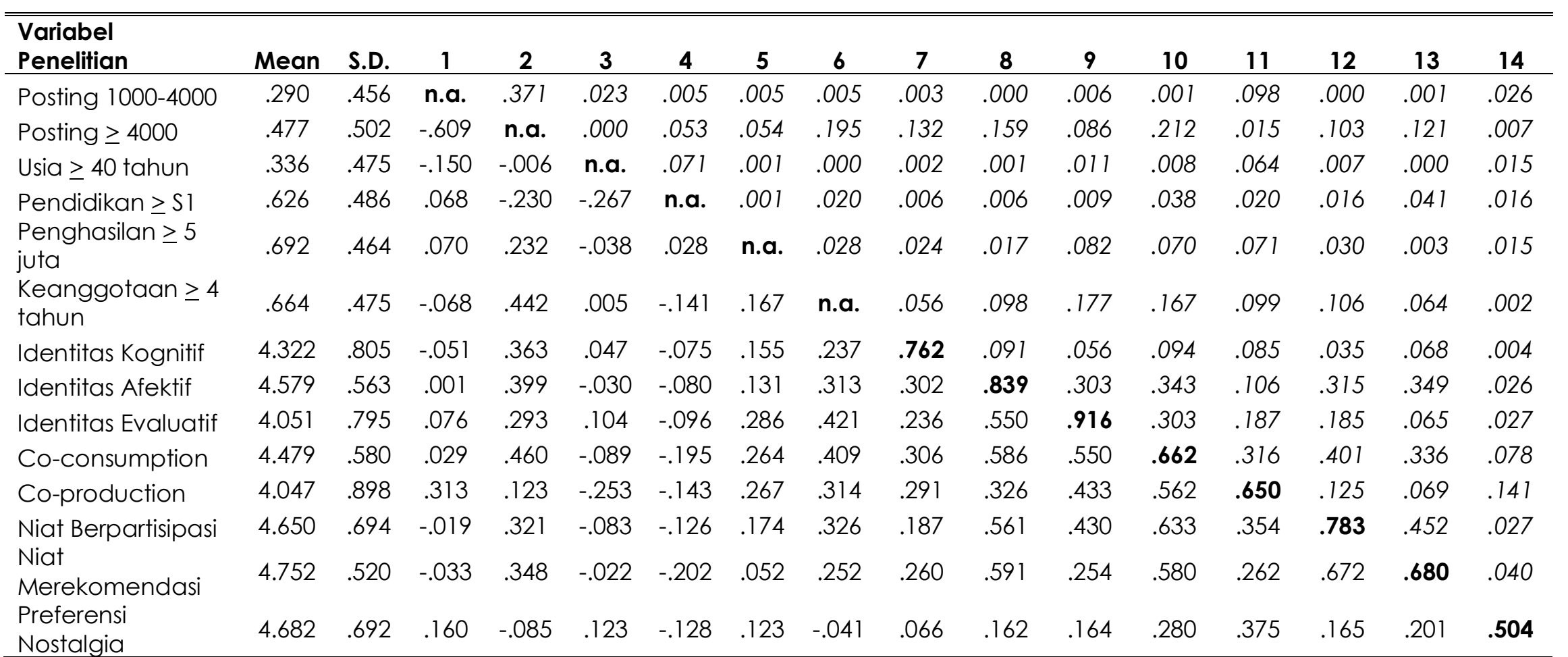

Keterangan: n.a. menunjukkan tidak ada; angka yang terdapat pada diagonal dan dicetak tebal adalah AVE; angka yang terletak diatas diagonal dan tercetak miring adalah kuadrat dari nilai korelasi; angka korelasi > 0,195 menujukkan signifikasi pada p < 0,05; angka korelasi > 0,252 menunjukkan signifikansi pada $p<0,01$ 
Hipotesa pertama menyatakan bahwa identitas sosial yang dimiliki oleh anggota komunitas online VW memiliki pengaruh yang positif terhadap co-creation dan niat berperilaku mereka terkait dengan komunitas. Hasil analisa menunjukkan bahwa identitas sosial memiliki pengaruh yang positif terhadap co-creation $\left(\beta_{1}=0,516, t=7,274\right)$ dan niat berperilaku anggota untuk berpartisipasi dalam kegiatan komunitas di masa datang maupun merekomendasikannya ke kolega $\left(\beta_{2}=0,398, t=3,671\right)$, sehingga $H_{1}$ terkonfirmasi dalam penelitian ini. Hipotesa kedua memprediksi bahwa berbagi informasi antar anggota maupun terhadap produsen VW akan berpengaruh secara positif terhadap niat berperilaku anggota untuk berpartisipasi maupun merekomendasikan komunitas VW ( $\beta_{3}=0,352$, $t=3,592$ ), sehingga $\mathrm{H}_{2}$ dalam penelitian ini juga terkonfirmasi. Hipotesa ketiga menyatakan bahwa pengaruh identitas sosial terhadap niat berperilaku anggota akan dimediasi oleh aktifitas co-creation yang mereka lakukan. Terlihat bahwa efek langsung yang dimiliki oleh identitas sosial terhadap niat berperilaku sebesar 0,398, adapun efek tidak langsung melalui aktifitas co-creationsebesar 0,182 (0,352 x 0,517); sehingga efek langsung memiliki koefisien yang lebih besar dibandingkan efek tidak langsung dan menyebabkan $\mathrm{H}_{3}$ tidak dapat diterima.

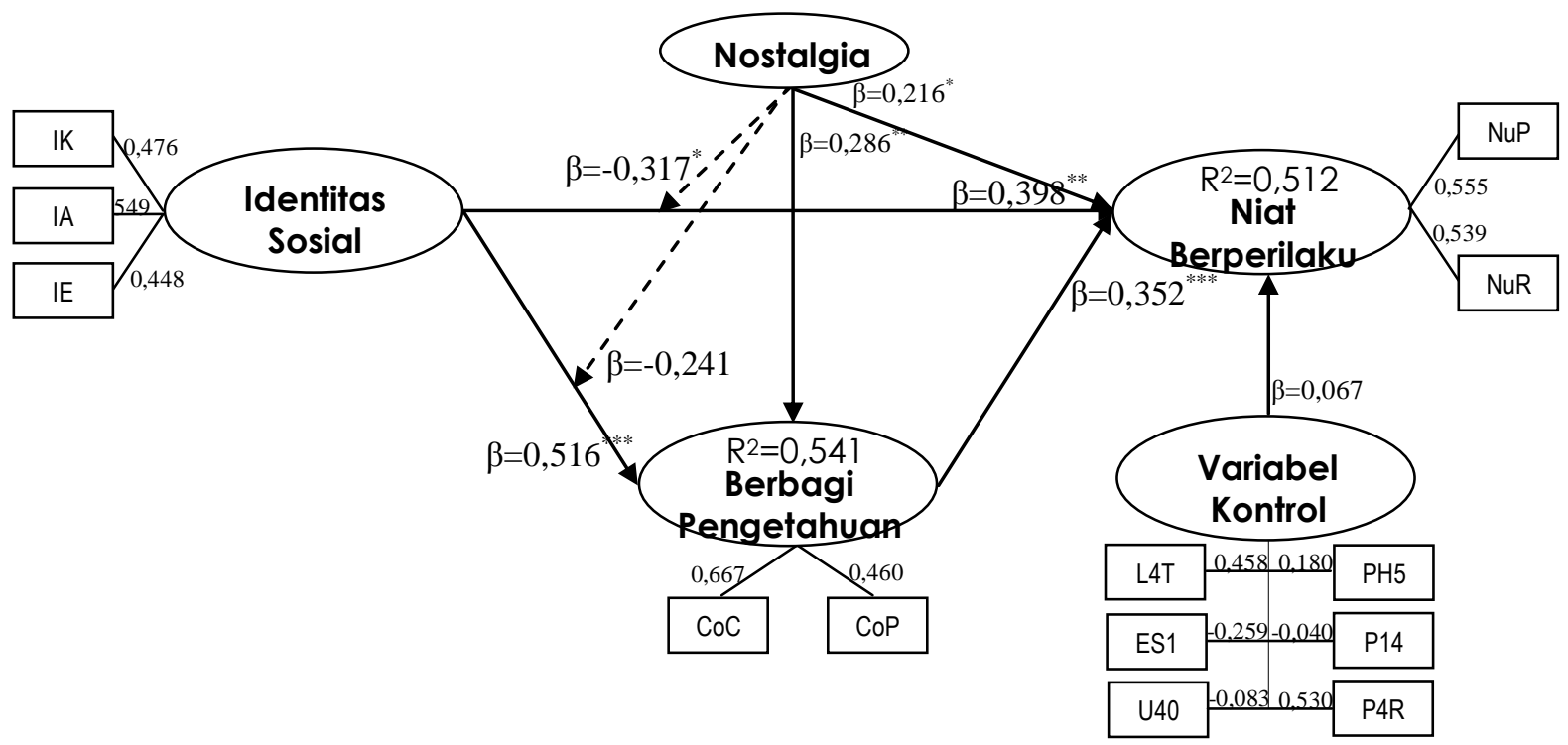

Catatan:

- IK=identitas kognitif, IA=identitas afektif, IE=identitas evaluative, $\mathrm{CoC}=\mathrm{co}$ consumption, $\mathrm{CoP}=\mathrm{co}-$ production, NuP=niat untuk partisipasi, NuR=niat untuk rekomendasi, L4T=lama menjadi anggota $\geq 4$ tahun, ESI=edukasi $\geq S 1$, U $40=u$ sia $\geq 40$ tahun, $\mathrm{PH} 5=$ penghasilan $\geq 5$ juta, $\mathrm{P} 14=$ posting antara 1000-4000, $\mathrm{P} 4 \mathrm{R}=$ posting $\geq 4.000$.

- + menunjukkan $\mathrm{p}<0,100$, * menunjukkan $\mathrm{p}<0,05$, ** menunjukkan $\mathrm{p}<0,01,{ }^{* * *}$ menunjukkan $p<0,001$

\section{Gambar 1 - Model Penelitian}

Hipotesa keempat menyatakan bahwa pengaruh positif identitas sosial terhadap aktifitas co-creation dan niat berperilaku akan dimoderasi oleh preferensi nostalgia yang dimiliki oleh anggota. Guna mengujinya, peneliti mengikuti prosedur yang digunakan oleh Gray dan Meister (2004), peneliti memodelkannya dengan menginteraksikan variabel identitas sosial dengan preferensi nostalgia konsumen sebagai moderator menggunakan metode centering seperti yang disarankan oleh Frazier, Tix dan Barron (2004). Misalnya, untuk menjelaskan bagaimana pengaruh tingkat preferensi nostalgia konsumen terhadap hubungan antara identitas sosial dengan aktifitas berbagi pengetahuan, peneliti menciptakan nama variabel interaksi baru dengan identitas sosial*preferensi nostalgia. 


\section{Badri Munir Sukoco Untung Teko TP}

Mengingat variabel identitas sosial memiliki 2 dimensi dan preferensi nostalgia memiliki 6 item, maka terdapat 12 item hasil interaksi keduanya. Hasil analisa menunjukkan bahwa efek moderasi tersebut hanya terlihat pada pengaruh identitas sosial pada niat berperilaku anggota komunitas $\left(\beta_{4}=0,317, t=2,160\right)$, sedangkan pengaruhnya pada aktifitas cocreation tidak signifikan $\left(\beta_{5}=-0,241, t=0,842\right)$, sehingga hanya $\mathrm{H}_{4 \mathrm{~b}}$ yang terdukung. Berikut adalah model penelitian yang diuji menggunakan koefisien jalur menggunakan PLS.

Hasil analisa lebih lanjut menunjukkan preferensi nostalgia anggota komunitas berpengaruh secara langsung terhadap aktifitas co-creation $(\beta=0,286, t=3,294)$, namun tidak signifikan terhadap niat berperilaku mereka $(\beta=0,216, t=2,498)$. Terkait dengan variabel kontrol, pengaruhnya terhadap niat berperilaku tidak signifikan ( $\beta=0,067, t=0,772$ ). Yang memiliki pengaruh signifikan dalam membentuk variabel control adalah anggota yang memiliki lama keangotaaan lebih dari 4 tahun dan yang telah melakukan posting lebih dari 4.000 kali.

Menggunakan prosedur dari Aiken dan West (1991) dan Cohen, Cohen, West, dan Aiken (2003), peneliti menggambarkan efek moderasi tersebut (Gambar 2). Tidak terdapat perbedaan yang signifikan antara niat berperilaku anggota yang memiliki preferensi nostalgia tinggi ( $\bar{X}=4,942)$ maupun rendah $(\bar{X}=5,012)$ ketika mereka memiliki identitas sosial yang tuinggi terhadap VICC. Namun ketika mereka memiliki identitas sosial yang rendah, terlihat bahwasanya anggota yang memiliki preferensi nostalgia yang lebih tinggi memiliki niat untuk ikut berpartisipasi maupun merekomendasikan VICC jauh lebih tinggi $(\bar{X}=4,712)$ dibandingkan ketika mereka memiliki preferensi nostalgia yang rendah $(\bar{X}=4,230)$.

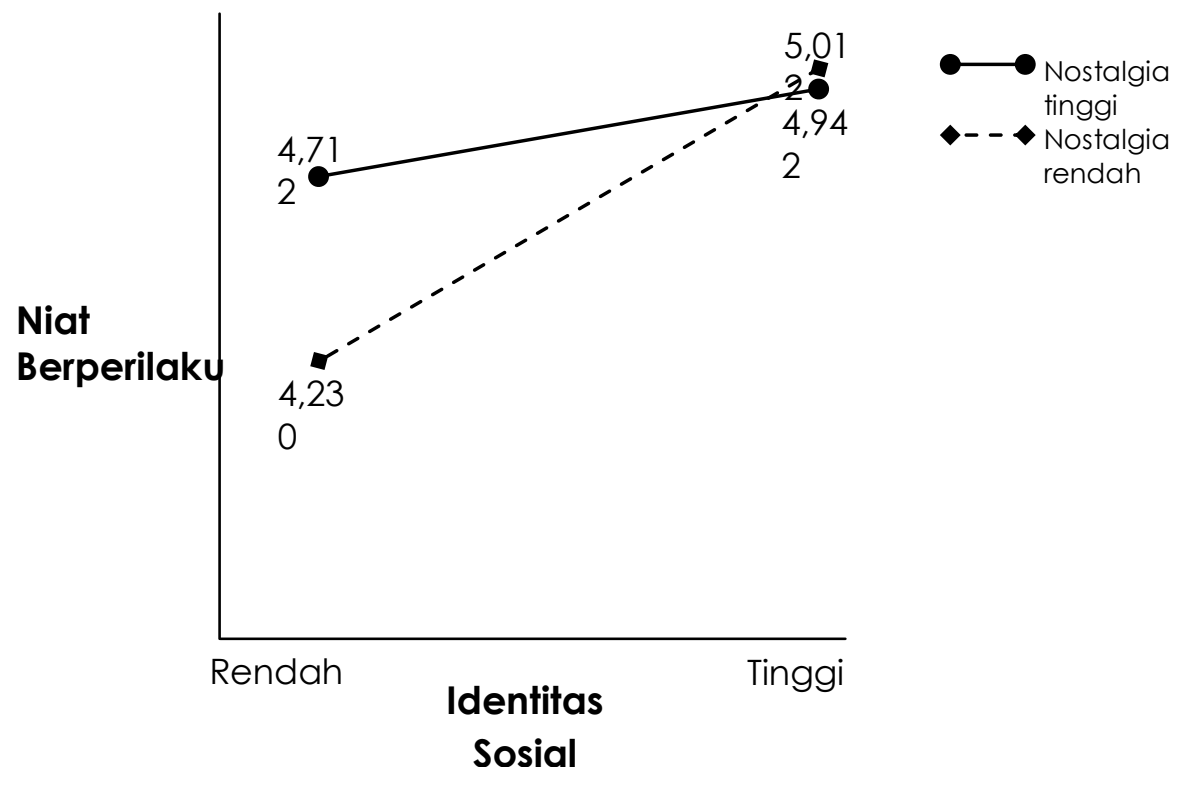

Gambar 2 - Efek Moderasi Preferensi Nostalgia Anggota VICC

\section{HASIL DAN PEMBAHASAN}

Penelitian ini menginvestigasi apakah identitas sosial yang dimiliki oleh anggota komunitas berkontribusi pada aktifitas co-creation dan niat berperilaku. Hasil analisa menujukkan bahwa identifikasi terhadap brand community mendorong anggota untuk aktif dalam cocreation dan co-consumption. Hal ini sejalan dengan argumentasi yang dikembangkan oleh Wu dan Sukoco (2010) dan Sukoco dkk. (2011) bahwa meningkatkatnya identifikasi sosial akan mendorong anggota untuk saling berbagi, baik dengan produsen maupun konsumen. Selain itu, penemuan ini juga sejalan dengan argumentasi yang dibangun oleh Algesheimer dkk. (2005) dan Bagozzi dan Dholakia (2006a, 2006b) bahwa identifikasi sosial mendorong 
anggota untuk selalu berpartisipasi dalam kegiatan komunitas maupun selalu merekomendasikannya kepada kolega.

Selain itu, seperti yang disampikan oleh Schau, Muniz, dan Arnould (2009), peneliti juga menemukan bahwa aktifitas berbagi pengetahuan yang dilakukan oleh anggota akan semakin memperkuat niatan mereka untuk berpartisipasi dan merekomendasikan komunitas kepada orang lain. Hal ini dikarenakan mereka ingin agar pengguna merek yang sama merasakan fun dan pada saat yang sama mendorong mereka untuk meng-upgrade pengetahuan mereka (Sukoco dan Wu, 2010). Meskipun pada hasil analisa lanjutan menujukkan bahwa pengaruh identitas sosial terhadap perilaku anggota tidak dimediasi oleh co-creation, namun hasil ini juga semakin menguatkan argumentasi yang dikembangkan berdasarkan teori identitas sosial bahwa identifikasi diri terhadap komunitas merupakan aspek yang paling krusial bagi anggota komunitas (Algesheimer dkk., 2005; Bagozzi dan Dholakia, 2006a, 2006b; dan Muniz dan O'Guinn, 2001).

Pertanyaan berikutnya adalah apakah pengaruh identitas sosial terhadap co-creation dan niat berperilaku anggota akan dimoderasi oleh preferensi nostalgia. Hasil analisa menunjukkan bahwa pengaruh tersebut ada pada hubungan antara identitas sosial dengan niat berperilaku, dimana ketika konsumen memiliki identitas sosial yang redah dengan VICC, mereka cenderung memiliki niat utuk berpartisipasi atau merekomendasi lebih tinggi bilamana mereka memiliki preferensi nostalgia yang juga tinggi. Hal ini juga menguatkan argumentasi yang dibuat sebelumnya bahwa tingkat legendaris sebuah merek (Holbrook dan Schindler, 1996; 2003) dapat berperan dalam membangkitkan niatan baik anggota untuk berbuat lebih banyak untuk komunitas.

Hasil penelitian ini mempunyai implikasi manajerial sebagai berikut: Pertama, komunitas virtual merupakan salah satu tempat dimana individu dapat berhubungan sosial, berinteraksi dan co-creationtanpa dipisahkan oleh jarak. Kemudahan individu dalam memberikan informasi maupun mengkonsumsi informasi tersebut merupakan peluang bagi para pemasar untuk menggali informasi tentang produk mereka dalam komunitas virtual. Mengelola komunitas dengan meningkatkan identifikasi sosial terhadap brand community akan mendorong mereka co-produce dengan produsen, layaknya anggota komunitas Nike (Fuller dkk., 2008) maupun VW New Beetle (Brown dkk., 2003). Kedua, pemasar harus menyadari bahwa produk dimana konsumennya mempunyai preferensi nostalgia yang tinggi dimungkinkan memiliki pengaruh yang lebih positif bagi brand community. Untuk itu, pemasar hendaknya harus kreatif dalam merancang kegiatan yang dapat membangkitkan nostalgia mereka akan merek yang diusung, seperti yang dilakukan oleh Nutella Community (Cova dan Pace, 2006) atau melakukan Jeep Jambore (McAlexander dkk., 2002).

Selain implikasi manajerial, penelitian ini juga mempunyai implikasi akademis. Pertama, penelitian ini melakukan validasi identitas sosial sebagai perspektif yang menjelaskan brand community, yang selama ini didominasi oleh konteks Barat (Bagozzi dan Dholakia, 2006; Muniz dan Schau, 2005). Kedua, penelitian ini juga memperkaya studi yang menitikberatkan pada proses co-creation yang dilakukan di dalam sebuah komunitas, baik co-consumption dan co-production (Wu dan Sukoco, 2010; Sukoco dan Aditya, 2011). Ketiga, menggunakan preferensi nostalgia (Holbrook dan Schindler, 1996, 2003), peneliti mencoba menguji asumsi apakah merek yang legendaries dan tentunya dapat membangkitkan preferensi nostalgia konsumen mendorong konsumen untuk lebih "berbuat bagi komunitasnya. Integrasi preferensi nostalgia dalam brand community selama ini masih terjembatani dengan baik, meskipun banyak studi yang menggunakan merek legendaries ketika mendiskusikan brand community (Brown dkk., 2003; Muniz dan Schau, 2005).

Meskipun penelitian ini telah dilakukan dengan baik, namun masih terdapat beberapa keterbatasan. Pertama, penelitian ini terbatas hanya pada komunitas virtual di Indonesia yang notabene memiliki kolektifisme relatif tinggi (Hofstede, 1980). Penelitian selanjutnya dapat memperbandingkan apakah kolaborasi inovatif berbeda antara negara dengan nilai 


\section{Badri Munir Sukoco \\ Untung Teko TP}

kolektifisme dan individualisme yang berbeda (Sukoco dkk., 2011). Kedua, penelitian ini menggunakan hanya satu merk, VW, yang cenderung mewakili produk high involvement (Zaichkowsky, 1985). Penelitian selanjutnya dapat menggunakan tipologi produk yang lain, misalnya hedonic vs. utilitarian, guna menginvestigasi kolaborasi inovatif. Ketiga, meskipun tujuan utama penelitian ini adalah berkontribusi pada literatur kolaborasi inovatif berdasarkan perspektif identitas sosial, menggabungkanya dengan dengan perspektif sosial cognitive (Hsu, Ju, Yen, dan Chang, 2007) maupun MOA (Wu dan Sukoco, 2010) tentunya akan meningkatkan kontribusinya.

\section{DAFTAR REFERENSI}

Aiken, L.S., dan West, S.G. 1991. Multiple Regression: Testing and Interpreting Interactions. Newbury Park: Sage.

Algesheimer, R., Dholakia, U.M., dan Herrmann, A. 2005. The sosial influence of brand community: evidence from European car clubs. Journal of Marketing 69, 19-34.

Bagozzi, R.P., dan Dholakia, U.M. 2006a. Open Source Software User Communities: A Study of Participation in Linux User Groups. Management Science 52/7 1099-1115.

Bagozzi, R.P., dan Dholakia, U. M. 2006b. Antecedents and purchase consequences of customer participation in small group brand communities. International Journal of Research in Marketing 23, 45-61.

Bagozzi, R.P., dan Lee, K-H. 2002. Multiple routes for sosial influence: The role of compliance, internalization, and sosial identity. Sosial Psychology Quarterly 65, 226-247.

Belk, R. W. (ed.) 1991 Highways and Buyways: Naturalistic Research From the Consumer Behavior Odyssey, Association for Consumer Research, Provo, UT.

Bergami, M., dan Bagozzi, R.P. 2000. Self-categorization, affective commitment, and group self-esteem as distinct aspects of sosial identity in an organization. British Journal of Sosial Psychology 39, 555-577.

Brown, A.D., dan Humphreys, M. 2002. Nostalgia and the narrativization of identity: A Turkish case study. British Journal of Management 13/2, 141-159.

Brown, S., Kozinets, R.V., Jr., dan Sherry, J.F. 2003. Teaching Old Brands New Tricks: Retro Branding and the Revival of Brand Meaning. Journal of Marketing, 67/3, 19-33.

Chin, W.W. 1998. The Partial Least Squares Approach for Structural Equation Modeling. In: Modern Methods for Business Research, ed. G.A. Marcoulides. Mahwah, NJ: Lawrence Erlbaum Associates, 295-336.

Cohen, J., Cohen, P., West, S.G., dan Aiken, L.S. 2003. Applied Multiple Regression/Correlation Analysis for the Behavioral Sciences 3rd Ed. Hillsdale: Erlbaum.

Cova, B., dan Pace, S. 2006. Brand community of convenience products: New forms of customer empowerment - The case of "my Nutella the community. European Journal of Marketing 40, 1087-1105.

Ellemers, N., Kortekaas, P., dan Ouwerkerk, J.W. 1999. Self-categorisation, commitment to the group and group self-esteem as related but distinct aspects of sosial identity. European Journal of Sosial Psychology 29, 371-389.

Feldman, J.M., dan Lynch, Jr. J.G. 1988. Self-generated validity and other effects of measurement on belief, attitude, intention, and behavior. Journal of Applied Psychology, 73, 421-35.

Fornell, C., dan Larcker, D.F. 1981. Evaluating structural equation models with unobservable variables and measurement error. Journal of Marketing Research 18/1, 39-50.

Frazier, P.A., Tix, A.P., dan Barron, K.E. 2004. Testing moderator and mediator effects in counseling psychology research. Journal of Counseling Psychology 51, 115-134.

Füller, J., Jawecki, G., dan Mühlbacher, H. 2007. Innovation Creation by Online Basketball Communities. Journal of Business Research, 60 (1), 60-71.

Füller, J., Matzler, K., dan Hoppe, M. 2008. Brand community members as a source of innovation. Journal of Product Innovation Management, 25, 608-619.

Ghozali, I. 2011 . Structural Equation Modelling Metode Alternatif dengan Partial Least Square. Edisi 3. Badan Penerbit Universitas Diponegoro. Semarang. 
Gray, P.H. dan Meister, D.B. 2004. Knowledge sourcing effectiveness. Management Science $50 / 6,821-34$.

Hobsbawm, E., dan Ranger, T. 1983. The Invention of Tradition (eds). Cambridge: Cambridge University Press.

Hofstede, G. 1980. Culture's Consequences: International Differences in Work-related Values. Beverly Hills, CA, Sage Publications.

Holbrook, M. B. 1993. Nostalgia and consumption preferences: Some emerging patterns of consumer tastes. Journal of Consumer Research 20/2, 245-256.

Holbrook, M.B. dan Schindler, R.M. 1996. Market segmentation based on age and attitude toward the past: Concepts, methods, and findings concerning nostalgic influences on customer tastes. Journal of Business Research 37/September, 27-39.

Holbrook, M.B., dan Schindler, R.M. 2003. Nostalgic bonding: Exploring the role of nostalgia in the consumption experience. Journal of Consumer Behaviour 3/2, 107-127.

Hsu, M.-H., Ju T.-L., Yen, C.-H., dan Chang C.-M. 2006. Knowledge Sharing Behavior in Virtual Communities: The Relationship between Trust, Self-efficacy, \& Outcome Expectations. International Journal of Human-Computer Studies, 65 (2), 153-169.

Kleijnen, M., Ruyter, K., dan Wetzels, M. 2007. An assessment of value creation in mobile service delivery and the moderating role of time consciousness. Journal of Retailing 83/1, $33-46$.

Koh, J. dan Kim, Y.G. 2004. Knowledge sharing in virtual communities: An e-business perspective. Expert Systems with Applications 26, 155-166.

Kozinets, R.V. 2002. The Field Behind the Screen: Using Netnography for Marketing Research in Online Communities. Journal of Marketing Research 39/1, 61-72.

Leigh, T.W., Peters, C., dan Shelton, J. 2006. The Consumer Quest for Authenticity: The Multiplicity of Meanings Within the MG Subculture of Consumption. Journal of the Academy of Marketing Science, 34/4, 481-493.

Lowenthal, D. 1985. The Past is a Foreign Country, Cambridge University Press, Cambridge, UK.

McAlexander, J.H., dan Schouten, J.W. 1998. Brandfests: Servicescapes for the Cultivation of Brand Equity, in Servicescapes: The Concept of Place in Contemporary Markets, ed. John F. Sherry, Jr., Chicago: NTC Business Books, 377-402

McAlexander, J.H., Schouten, J.W., dan Koenig, H.F. 2002. Building brand community. Journal of Marketing 66, 38-54.

Muniz, A.M., dan O'Guinn, T.C. 2001. Brand community. Journal of Consumer Research, 27 (2), 412-432.

Muniz, A.M., dan Schau H.J. 2005. Religiosity in the Abandoned Apple Newton Brand Community. Journal of Consumer Research, 31 (1), 737-747.

Podsakoff, P.M., dan Organ, D.W. 1986. Self-reports in organizational research: Problems and prospects. Journal of Management 12, 531-544.

Podsakoff, P.M., MacKenzie, S.B., Lee, J.Y., dan Podsakoff, N.P. 2003. Common method biases in behavioral research: A critical review of the literature and recommended remedies. Journal of Applied Psychology 88, 879-903.

Prahalad, C.K., dan Ramaswamy, V. 2004. Co-creation experiences: The next practice in value creation. Journal of Interactive Marketing, 18, 5-14.

Rheingold, H. 1994. A slice of life in my virtual community global networks: Computers and international communication. In L. M. Harasim (Ed.). Global Networks: Computers and International Communication (pp. 57-80). Cambridge, MA: MIT Press.

Ryu, S., Ho, S.H., dan Han, I. 2003. Knowledge sharing behavior of physicians in hospitals. Expert Systems with Applications 25, 113-122.

Schau, H.J., Muniz, A.M., dan Arnould, E.J. 2009. How brand community practices create value. Journal of Marketing 72, 30-51.

Schouten, J.W., dan McAlexander, J. 1995. Subcultures of Consumption: An Ethnography of the New Bikers. Journal of Consumer Research 22/June, 43-61.

Sproull, L., dan Arriaga, M. 2007. Online Communities, in H. Bidogli, ed. Handbook of Computer Networks, Vol. 3. John Wiley \& Sons, New York. 


\section{Badri Munir Sukoco}

\section{Untung Teko TP}

Stets, J.E., dan Burke, P.J. 2000. Identity Theory and Sosial Identity Theory. Sosial Psychology Quarterly 63, 224-237.

Sukoco, B.M. dan Aditya, M.L. 2011. Pengaruh Nilai Informasi dan Sosial pada Coconsumption dan Co-production antar Anggota Kaskus: Perspektif Modal Sosial. Jurnal Manajemen Teknologi 10/3, 264-280

Sukoco, B.M., dan Setiawan, A.M. 2013. Pengaruh Sense of Community terhadap Berbagi Pengetahuan pada Komunitas Nikon: Efek Moderasi Individualisme Anggota. Proceedings Seminar Nasional Forum Manajemen Indonesia (FMI) 5, Pontianak, 23-24 Oktober 2013.

Sukoco, B.M., dan Wu, W-Y. 2010. The personal and sosial motivation of customers' participation in brand community. African Journal of Business Management 4/5, 614-622.

Sukoco, B.M., Wu, W-Y., dan Loh, A.L.C. 2011. The Effect of Member Identification across Cultures inside a Brand Community. Proceedings of Academy of International Business (AIB) Conference, Nagoya, Jepang; 24-28 Juni 2011

Tajfel, H. 1978. Sosial categorization, sosial identity, and sosial comparison. In H. Tajfel (Ed.). Differentiation between sosial groups: Studies in the sosial psychology of intergroup relations (pp. 61-67). London: Academic Press.

Thompson, S.A., dan Sinha, R.K. 2008. Brand communities and new product adoption: The Influence and limits of oppositional loyalty. Journal of Marketing 72, 65-80.

von Loewenfeld, F. 2006. Brand Communities - Erfolgsfaktoren und ökonomische Relevanz von Markengemeinschaften. Wiesbaden: Deutscher Universitäts-Verlag.

Wu, W-Y., dan Sukoco, B.M. 2010. Why Should I Share? Examining Consumers' Motives and Trust on Knowledge Sharing. Journal of Computer Information Systems, 50/4, 11-19.

Zaichkowsky, J.L. 1985. Measuring the involvement construct. Journal of Consumer Research $12,341-352$.

Zhang, Z-J. 2010. Feeling the sense of community in sosial networking usage. IEEE Transactions on Engineering Management, 57/2, 2010. 